\title{
携帯型低インピーダンスメータ
}

増 田 好 治* - 一 條 文二郎** - 藤 井 道 彦*

\section{The Portable Type of Low-Impedance Meter}

\author{
Yoshiharu MASUDA*, Bunjiro ICHIJO** \\ and Michihiko FuJII*
}

Recently in the field of agriculture, demands for convenient measurement of water contents in rockwool and sand, concentration of nutrient solution, and plant physiological information with the change of environments, are increasing. This paper shows the characteristics and applications of resistancecapacitance meter composed of two resonant circuits, which is developed to solve these problems. By this resistance-capacitance meter, capacitance and resistance of specimen can be measured by both zero method and deflection method, and small changes in resistance can be measured by deflection method. Measurement sensitivity can be changed freely by fitting values of circuit elements (capacitor) adequately. Since circuit composition of this measurement instrument is very simple, demands for the one of small size and portability are satisfied. Measurement of capacitance and resistance corresponding to the water contents of sand including electrolyte were shown as the applications, and continuous measurement of water status in rice, though it has been regarded as difficult, and the effect of magnetic field on capacitance and resistance of the leaf of plants were shown as the example for detecting plant physiological information.

Key Words : low-impedance, capacitance, resistance, plant physiological information, magnetic field

\section{1.はじめに}

最近，農業の分野においてロックウールや砂地の中の 水分量や培養液濃度の測定が可能で, しかも小型で低価 格の測定器に対する要求が高まっている。また，植物を 生育状態のままで，その環境要因の変化に対する生体情 報を簡便に測定したいという要求も強い1).これまで, 試 料の等価並列抵抗にして,無限大から約 20 オームという 広範囲において，その抵抗值の影響を受けないで試料の 容量値，および抵抗值の測定が可能な高周波抵抗容量計 がいくつか開発された2)

しかし，これらの抵抗容量計はいずれも4 個あるいは 3 個の同調回路から構成されるので，それらに付随する 回路素子を考慮すると, 測定器として組み上がったものは かなりの大きさとなり携帯型としては不向きであった。

本論文は，新しく開発された 2 個の同調回路と 1 個の

\footnotetext{
* 静岡大学教育学部 静岡市大谷 836

** 浜松衛生短期大学 浜松市三方原町 3453

* Faculty of Education, Shizuoka University, Shizuoka

** Hamamatsu Hygienic College, Hamamatsu (Received March 8, 1993)
}

(Revised May 7, 1993)
水晶発信子から構成され，低インピーダンスおよびそれ らの微少変化の測定が可能な携帯型抵抗容量計の動作原 理，回路特性および応用例について述べる.

\section{2. 低インピーダンスと炎の微少変化の測定原理}

Fig. 1 は測定回路図である。 2 個の同調回路に用いら れるコイルは同じ構造に作られているので, そのインダ クタンスおよびステップアップ・レシオはそれぞれ等し い $\left(L_{0}=L_{1}, Q_{0}=Q_{1}\right)$ ，第 1 同調回路がコンデンサ $C_{0} を$ 介して高周波発信器に接続され, 第 2 同調回路がコンデ ンサ $C_{01}$ を介して第 1 回路に接続される. $\left(R_{x}, C_{x}\right)$ は試

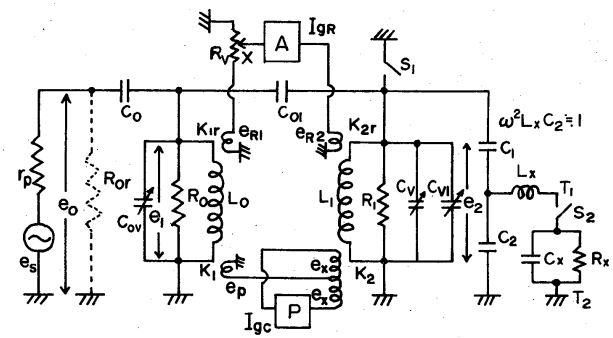

Fig. 1 Measuring circuit diagram 
料の抵抗および容量である. $L_{x}$ は電極と測定器を接続 するリード線(同軸ケーブル)のインダクタンスであり, $\omega^{2} L_{x} C_{2}=1$ の条件を満足させることにより, 試料の抵抗 $R_{x}$ が容量測定に及ぼす影響を取り除くことができ る $^{3), 5)}$. この $\omega^{2} L_{x} C_{2}=1$ の条件による効果および 3 端子 の小型高周波発信子の使用により同調回路を減らすこと が可能となった：可変抵抗 $R_{v}$ が接続された第 1 回路は $R_{x}$ (たとえば培養液濃度)を測定する働きをし, 第 2 回路 は $C_{x}$ (たとえば水分量)を測定する働きをする.

\section{1 零位法による $C_{x}$ の測定}

Fig. 1 において,端子電圧 $e_{1}, e_{2}$ は,つぎの関係が満足さ れたとき最大值をとり, $e_{p}$ に対して $90^{\circ}$ の位相差を生じる6).

$$
\begin{aligned}
& \omega^{2} L_{0}\left(C_{0}+C_{0 v}+C_{01}\right)=1 \\
& \omega^{2} L_{1}\left(C_{01}+C_{v}+C_{v 1}+\frac{C_{1} C_{2}}{C_{1}+C_{2}}\right)=1
\end{aligned}
$$

上の条件を得るためには, スイッチ $S_{1}$ を閉じ, $e_{1}$ または $e_{p}$ が最大になるように $C_{0 v}$ を調整し，つぎに，スイッチ $S_{1}$ を開いた状態で電圧 $e_{2}$ または $e_{x}$ が最大になるよう に $C_{v}$ を調整する. 出力 $I_{g c}$ は, $I_{g c}=4 K e_{p} e_{x} \tan \theta$ で表 わされる。

ここに, $K$ は検出器 $P$ の定数, $\theta$ は $C_{x}$ による $e_{x}$ の 位相変化量である.したがって, 試料 $\left(C_{x}, R_{x}\right)$ による容 量出力 $I_{g c}$ は次式で表わされる.

$$
\begin{aligned}
I_{g c}= & 4 K K_{1} K_{2} \\
& \cdot \frac{\omega^{2} C_{0}^{2} R_{0}^{2} \cdot \omega C_{01} R_{1} \cdot R_{x}\left(1+C_{2} / C_{1}\right)^{2}}{\left\{R_{1}\left(1+\omega^{2} C_{0}^{2} R_{0} r_{p}\right)+R_{x}\left(1+C_{2} / C_{1}\right)^{2}\right.} * \\
& * \frac{\times \omega C_{x} R_{x} R_{1} e_{s}^{2}}{\left.\times\left(1+\omega^{2} C_{0}^{2} R_{0} r_{p}+\omega^{2} C_{01}^{2} R_{1} R_{0}\right)\right\}^{2}}
\end{aligned}
$$

$\left(C_{x}, R_{x}\right)$ に対する出力 $I_{g c}$ はつぎの条件を満足したとき 最大となる.

$$
\begin{aligned}
& R_{x}\left(1+C_{2} / C_{1}\right)^{2}=R_{1} / 2 \\
& \omega^{2} C_{01}^{2} R_{1} R_{0}=\omega^{2} C_{01}^{2} R_{1}^{2}=3 \quad\left(\because R_{1}=R_{0}\right) \\
& \omega^{2} C_{0}^{2} R_{0} r_{p}=2
\end{aligned}
$$

( 2 )〜 (4) 式および Fig. 1 における $R_{0 r}$ から,インピーダ ンス・マッチングの条件 $r_{p}=R_{0 r}$ が満足されたとき容量 出力は最大となり, その最大值 $I_{g c M}$ は次式で表わされる.

$$
I_{g c M}=4 K K_{1} K_{2} \cdot \frac{1}{12 \sqrt{3}} \cdot \frac{R_{0}}{r_{p}} \cdot \omega C_{x} R_{x} e_{s}^{2}
$$

\section{2 零位法による $\boldsymbol{R}_{x}$ の測定}

Fig. 1 において，スイッチ $S_{2}$ が開いた状態における $e_{R 1}, e_{R 2}$ はそれぞれ次式で表わされる。

$$
\begin{aligned}
& e_{R 1}=K_{1 r} e_{1}=\frac{K_{1 r} \cdot \omega C_{0} R_{0} e_{s}}{1+\omega^{2} C_{0}^{2} R_{0} r_{p}+\omega^{2} C_{01}^{2} R_{1} R_{0}} \\
& e_{R 2}=K_{2 r} e_{2}=\frac{K_{2 r} \cdot \omega C_{0} R_{0} \cdot \omega C_{01} R_{1} e_{s}}{1+\omega^{2} C_{0}^{2} R_{0} r_{p}+\omega^{2} C_{01}^{2} R_{1} R_{0}}
\end{aligned}
$$

試料の接続される前は, $e_{R 1}=e_{R 2}$ であり振幅検出器 $A$ の 出力 $I_{g R}$ は零である. スイッチ $S_{2}$ が閉じられ(試料が接
続された状態), $P$ の容量出力 $I_{g c}$ が $\Delta C_{v 1}$ によって零に されたときの $e_{R 1}, e_{R 2}$ の電圧 $e_{R 1 x}, e_{R 2 x}$ はそれぞれ次式 で表わされる。

$$
\begin{aligned}
& e_{R 1 x}=\frac{K_{1 r} \cdot \omega C_{0} R_{0}\left\{R_{1}+R_{x}\left(1+C_{2} / C_{1}\right)^{2}\right\} e_{s}}{\left\{\begin{array}{c}
R_{1}\left(1+\omega^{2} C_{0}^{2} R_{0} r_{p}\right)+R_{x}\left(1+C_{2} / C_{1}\right)^{2} \\
\times\left(1+\omega^{2} C_{0}^{2} R_{0} r_{p}+\omega^{2} C_{01}^{2} R_{1} R_{0}\right)
\end{array}\right\}} \\
& e_{R 2 x}=\frac{K_{2 r} \cdot \omega C_{0} R_{0} \cdot \omega C_{01} R_{1} R_{x}\left(1+C_{2} / C_{1}\right)^{2} e_{s}}{\left\{\begin{array}{c}
R_{1}\left(1+\omega^{2} C_{0}^{2} R_{0} r_{p}\right)+R_{x}\left(1+C_{2} / C_{1}\right)^{2} \\
\times\left(1+\omega^{2} C_{0}^{2} R_{0} r_{p}+\omega^{2} C_{01}^{2} R_{1} R_{0}\right)
\end{array}\right\}}
\end{aligned}
$$

ここで, $\Delta e_{R 1}=e_{R 1}-e_{R 1 x}, \Delta e_{R 2}=e_{R 2}-e_{R 2 x}$ とおくと, そ れぞれ次式が得られる。

$$
\begin{aligned}
\Delta e_{R 1}= & -e_{R 1} \\
& \times \frac{\omega^{2} C_{01}^{2} R_{1}^{2} R_{0}}{\left\{\begin{array}{c}
R_{1}\left(1+\omega^{2} C_{0}^{2} R_{0} r_{p}\right)+R_{x}\left(1+C_{2} / C_{1}\right)^{2} \\
\times\left(1+\omega^{2} C_{0}^{2} R_{0} r_{p}+\omega^{2} C_{01}^{2} R_{1} R_{0}\right)
\end{array}\right\}} \\
\Delta e_{R 2}= & e_{R 2} \\
& \times \frac{R_{1}\left(1+\omega^{2} C_{0}^{2} R_{0} r_{p}\right)}{\left\{\begin{array}{c}
R_{1}\left(1+\omega^{2} C_{0}^{2} R_{0} r_{p}\right)+R_{x}\left(1+C_{2} / C_{1}\right)^{2} \\
\times\left(1+\omega^{2} C_{0}^{2} R_{0} r_{p}+\omega^{2} C_{01}^{2} R_{1} R_{0}\right)
\end{array}\right\}}
\end{aligned}
$$

試料の抵抗值による出力電圧 $\Delta e_{\text {out }}$ は次式となる，ただ し, $e_{R 1}=e_{R 2}=e_{R}$ とする.

$$
\begin{aligned}
\Delta e_{\mathrm{OUT}}= & \left|\Delta e_{R 1}\right|+\left|\Delta e_{R 2}\right|=e_{R} \\
& \times \frac{R_{1}\left(1+\omega^{2} C_{0}^{2} R_{0} r_{p}+\omega^{2} C_{01}^{2} R_{1} R_{0}\right)}{\left\{\begin{array}{c}
R_{1}\left(1+\omega^{2} C_{0}^{2} R_{0} r_{p}\right)+R_{x}\left(1+C_{2} / C_{1}\right)^{2} \\
\times\left(1+\omega^{2} C_{0}^{2} R_{0} r_{p}+\omega^{2} C_{01}^{2} R_{1} R_{0}\right)
\end{array}\right\}}
\end{aligned}
$$

(10)式において, 容量出力が最大感度となる条件式, す なわち $\omega^{2} C_{01}^{2} R_{1} R_{0}=1+\omega^{2} C_{0}^{2} R_{0} r_{p}$ を代入すると次式が 得られる。

$$
\Delta e_{\mathrm{oUT}}=e_{R} \cdot \frac{2}{1+2 \cdot R_{x}\left(1+C_{2} / C_{1}\right)^{2} / R_{1}}
$$

振幅検出器 $A$ を可変抵抗器 $R_{v}$ の可動子 $X$ を調整する ことにより零とし, 既知抵抗 $R_{x}$ と可変抵抗器 $R_{v}$ の角 度との校正曲線から試料の未知抵抗 $R_{x}$ が決定される。

\section{3 偏位法による $\boldsymbol{\Delta \boldsymbol { R } _ { x }}$ の測定}

試料の抵抗 $R_{x}$ の微小変化 $\Delta R_{x}$ による出力 $I_{g R}$ につ いて考える. $U$ をつぎのように报くと， $\left(6^{\prime}\right),\left(7^{\prime}\right)$ 式から 次式が得られる。 $U=R_{1}\left(1+\omega^{2} C_{0}^{2} R_{0} r_{p}\right)+R_{x}(1$ $\left.+C_{2} / C_{1}\right)^{2}\left(1+\omega^{2} C_{0}^{2} R_{0} r_{p}+\omega^{2} C_{01}^{2} R_{1} R_{0}\right)$

$$
\begin{aligned}
\Delta e_{R 1}= & -e_{R 1 x} \frac{\omega^{2} C_{01}^{2} R_{1}^{2} R_{0}}{U} \\
& \times \frac{R_{x}\left(1+C_{2} / C_{1}\right)^{2}}{R_{1}+R_{x}\left(1+C_{2} / C_{1}\right)^{2}} \cdot \frac{\Delta R_{x}}{R_{x}} \\
\Delta e_{R 2}= & e_{R 2 x} \cdot \frac{R_{1}\left(1+\omega^{2} C_{0}^{2} R_{0} r_{p}\right)}{U} \cdot \frac{\Delta R_{x}}{R_{x}}
\end{aligned}
$$

しかし， $I_{g R}=0$ の状態においては $e_{R 1 x}=e_{R 2 x} \equiv e_{R x}$ であ るので次式が得られる。 


$$
\begin{aligned}
\Delta e_{\mathrm{OUT}}= & \left|\Delta e_{R 1}\right|+\left|\Delta e_{R 2}\right|=e_{R x} \cdot \frac{1}{U} \cdot \frac{\Delta R_{x}}{R_{x}} \\
& \times\left\{\frac{\omega^{2} C_{01}^{2} R_{1}^{2} R_{0} R_{x}\left(1+C_{2} / C_{1}\right)^{2}}{R_{1}+R_{x}\left(1+C_{2} / C_{1}\right)^{2}}\right. \\
& \left.+R_{1}\left(1+\omega^{2} C_{0}^{2} R_{0} r_{p}\right)\right\} \\
= & e_{R x} \cdot \frac{R_{1}}{R_{1}+R_{x}\left(1+C_{2} / C_{1}\right)^{2}} \cdot \frac{\Delta R_{x}}{R_{x}}
\end{aligned}
$$

結局 $\Delta R_{x}$ による出力は次式で表わされる.

$\Delta e_{\text {out }}$

$$
\begin{aligned}
= & \frac{K_{2 r} \cdot \omega C_{0} R_{0} \cdot \omega C_{01} R_{1} \cdot R_{x}\left(1+C_{2} / C_{1}\right)^{2} e_{s}}{\left\{\begin{array}{c}
R_{1}\left(1+\omega^{2} C_{0}^{2} R_{0} r_{p}\right)+R_{x}\left(1+C_{2} / C_{1}\right)^{2} \\
\times\left(1+\omega^{2} C_{0}^{2} R_{0} r_{p}+\omega^{2} C_{01}^{2} R_{1} R_{0}\right)
\end{array}\right\}} \\
& \times \frac{R_{1}}{R_{1}+R_{x}\left(1+C_{2} / C_{1}\right)^{2}} \cdot \frac{\Delta R_{x}}{R_{x}}
\end{aligned}
$$

$\left(13^{\prime}\right)$ 式は, $R_{x}$ による出力を可変抵抗器 $R_{v}$ により零に した状態における $\Delta R_{x}$ による出力を表わす。また $\left(13^{\prime}\right)$ 式における $\Delta e_{\text {OUT }}$ は，一定の $\Delta R_{x} / R_{x}$ に対してつぎの条 件を満足したとき最大值をとる.

$$
\begin{aligned}
& R_{x}\left(1+C_{2} / C_{1}\right)^{2} \\
& \quad=R_{1} \cdot \sqrt{\frac{1+\omega^{2} C_{0}^{2} R_{0} r_{p}}{1+\omega^{2} C_{0}^{2} R_{0} r_{p}+\omega^{2} C_{01}^{2} R_{1} R_{0}}}
\end{aligned}
$$

容量出力の最大感度の条件 $\omega^{2} C_{01}^{2} R_{1} R_{0}=1+\omega^{2} C_{0}^{2} R_{0} r_{p}$ を(14)式に代入することにより次式が得られる.

$$
R_{x}\left(1+C_{2} / C_{1}\right)^{2}=R_{1} / 2
$$

\section{4 偏位法による $C_{x}, \boldsymbol{R}_{x}$ の測定}

(1) 式において, $R_{x}\left(1+C_{2} / C_{1}\right)^{2}$ の值が $R_{1}$ に比べては るかに大きいとき，すなわち $R_{x}\left(1+C_{2} / C_{1}\right)^{2} \gg R_{1}$ のと き，(1)式は近似的に次式で表わされる.

$$
\begin{aligned}
I_{g c}= & 4 K K_{1} K_{2} \\
& \times \frac{\omega^{2} C_{0}^{2} R_{0}^{2} \cdot \omega C_{01} R_{1} \cdot \omega C_{x} R_{1} e_{s}^{2}}{\left\{\begin{array}{c}
\left(1+C_{2} / C_{1}\right)^{2}\left(1+\omega^{2} C_{0}^{2} R_{0} r_{p}\right. \\
\left.+\omega^{2} C_{01}^{2} R_{1} R_{0}\right)^{2}
\end{array}\right\}}
\end{aligned}
$$

この出力は $R_{x}$ の值が無限大のときの $C_{x}$ に対する検出 器の振れを示している. そこで, $R_{x}$ が無限大のとき, お よび有限の $R_{x}$ のときの $C_{x}$ に対する出力 $I_{g c}$ をそれぞ れ $I_{g C R X \infty}, I_{g C R X}$ とすると, その比 $I_{g C R X \infty} / I_{g C R X}$ は $R_{x}(1$ $\left.+C_{2} / C_{1}\right)^{2}$ の值が小さくなるにしたがって 1 より大きく なる. Table 1 の左欄は ( 1 )式からの計算結果である.

つぎに $R_{x}$ の測定について述べる.（6)と（7)式から 次式が得られる。

$\Delta e_{R 1}$

$$
\begin{aligned}
& =-\frac{K_{1 r} \cdot \omega C_{0} R_{0} \cdot \omega^{2} C_{01}^{2} R_{1} R_{0} e_{s}}{\left(1+\omega^{2} C_{0}^{2} R_{0} r_{p}+\omega^{2} C_{01}^{2} R_{1} R_{0}\right)^{2}} \cdot \frac{\Delta R_{1}}{R_{1}} \\
& =-e_{R 1} \cdot \frac{\omega^{2} C_{01}^{2} R_{1} R_{0}}{1+\omega^{2} C_{0}^{2} R_{0} r_{p}+\omega^{2} C_{01}^{2} R_{1} R_{0}} \cdot \frac{\Delta R_{1}}{R_{1}} \\
& =\frac{K_{2 r} \cdot \omega C_{0} R_{0} \cdot \omega C_{01} R_{1}\left(1+\omega^{2} C_{0}^{2} R_{0} r_{p}\right) e_{s}}{\left(1+\omega^{2} C_{0}^{2} R_{0} r_{p}+\omega^{2} C_{01}^{2} R_{1} R_{0}\right)^{2}}
\end{aligned}
$$

$\Delta e_{R 2}$
Table 1 Results calculated from equation $\left(1^{\prime}\right)$ and its experimental results

\begin{tabular}{l|c|c|c|c|c}
\hline \hline \multicolumn{3}{c|}{ Calculated results } & \multicolumn{3}{c}{ Experimental results } \\
$\omega^{2} C_{0}^{2} R_{0} r_{p}=2 \quad \omega^{2} C_{01}^{2} R_{1} R_{0}=1$ \\
$R_{1}=17 \mathrm{k} \Omega(1+C 2 / C 1)^{2}=3700$ \\
$f=10^{7} \mathrm{~Hz}$
\end{tabular}

$$
\begin{aligned}
& \times \frac{\Delta R_{1}}{R_{1}} \\
= & e_{R 2} \cdot \frac{1+\omega^{2} C_{0}^{2} R_{0} r_{p}}{1+\omega^{2} C_{0}^{2} R_{0} r_{p}+\omega^{2} C_{01}^{2} R_{1} R_{0}} \cdot \frac{\Delta R_{1}}{R_{1}}
\end{aligned}
$$

ここで $e_{R 1}=e_{R 2} \equiv e_{R 0}$ とおくと, $\Delta R_{1}$ による出力は次式 で表わされる。

$$
\begin{aligned}
\Delta e_{\mathrm{OUT}} & =\left|\Delta e_{R 1}\right|+\left|\Delta e_{R 2}\right|=e_{R 0} \cdot \frac{\Delta R_{1}}{R_{1}} \\
& =e_{R 0} \cdot \frac{R_{1}}{R_{1}+R_{x}\left(1+C_{2} / C_{1}\right)^{2}}
\end{aligned}
$$

(17) 式は $R_{x}$ による出力 $I_{g R}$ であるが, $R_{x}\left(1+C_{2} / C_{1}\right)^{2}$ $\gg R_{1}$ の条件のもとでは次式が得られる.

$$
\Delta e_{\mathrm{OUT}}=\frac{R_{1}}{R_{x}\left(1+C_{2} / C_{1}\right)^{2}} \cdot e_{R 0}
$$

このようにして検出器 $P$ および $A$ の振れから $C_{x}, R_{x}$ の值を測定することができる.

\section{3. 測定回路の特性}

Fig. 2 およびFig. 3 は, 周波数 $3 \mathrm{MHz}$ において, 結合 コンデンサ $C_{01}$ の值に対する容量出力 $I_{g c}$ の計算値およ び実験結果である. Fig. 4 は ( 1 ) 式における $\left(1+C_{2} / C_{1}\right)^{2}$ に対する出力 $I_{g c}$ の計算結果と実験結果である.（2)式 の条件が良く満足されていることがわかる.Fig. 5 は $R_{x}$ による出力 $I_{g R}$ を零にしたときの $R_{x}$ の值と可変抵抗器 $R_{v}$ のダイアル目盛りを調べた結果の一例である. $R_{x}$ の 測定範囲は $C_{2}$ と $C_{1}$ の比 $C_{2} / C_{1}$ の值を選ぶことにより 可変できる. したがって $R_{v}$ のダイアル目盛りから試料 $\left(C_{x}, R_{x}\right)$ の $R_{x}$ の值を測定することができる. Fig. 6 は 試料の $R_{x}$ および $G_{x}\left(=1 / R_{x}\right)$ と抵抗出力 $I_{g R}$ との関係 を示す実験結果である. Fig. 7〜8 はスイッチ $S_{2}$ を閉じ， 出力 $I_{g R}$ を零にした状態で $R_{x} に 1 \%$ 変化を与えたと きの $R_{x}$ と出力 $I_{g R}$ に関する実験結果である. (14') 式を 満足したとき $\Delta R_{x} / R_{x}$ に対する最大感度が得られること がわかる.Fig. 9 はいろいろな $R_{x}$ の值における $C_{x}$ に対 する容量出力 $I_{g c}$ の関係を示すものである. また, Table 


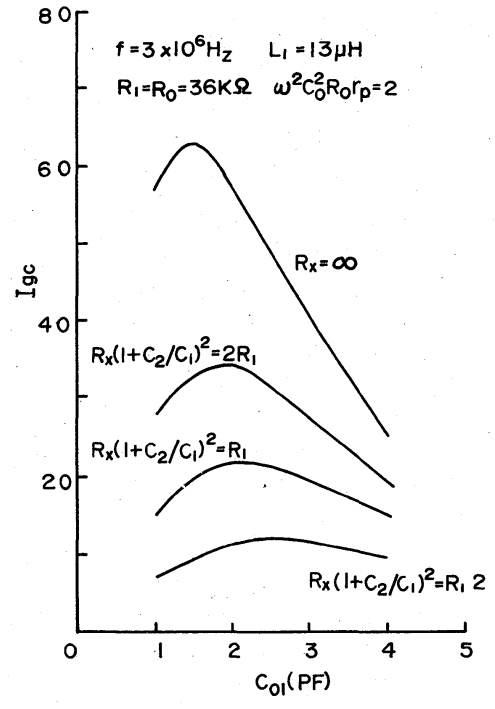

Fig. 2 Calculated results showing the relation between the output $I_{g c}$ and $C_{01}$ with $R_{x}$ being taken as parameter at $3 \mathrm{MHz}$

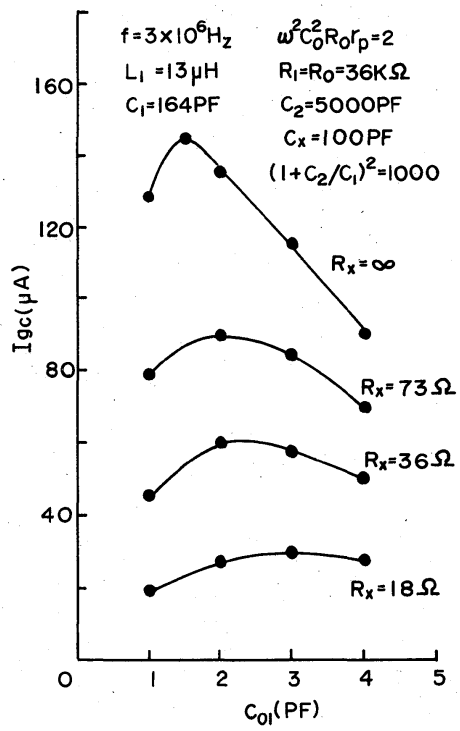

Fig. 3 Experimental results showing the relation between the output $I_{g c}$ and $C_{01}$ with $R_{x}$ being taken as parameter at $3 \mathrm{MHz}$

1 の右欄に示す $I_{g C R X \infty} / I_{g C R X}$ の実験值は計算値と良く一 致する。

\section{4. 応用例}

Fig. 10 は,この携帯用低インピーダンスメータを用い て， 3 種類の溶液濃度において, 砂の中の水分量に対す

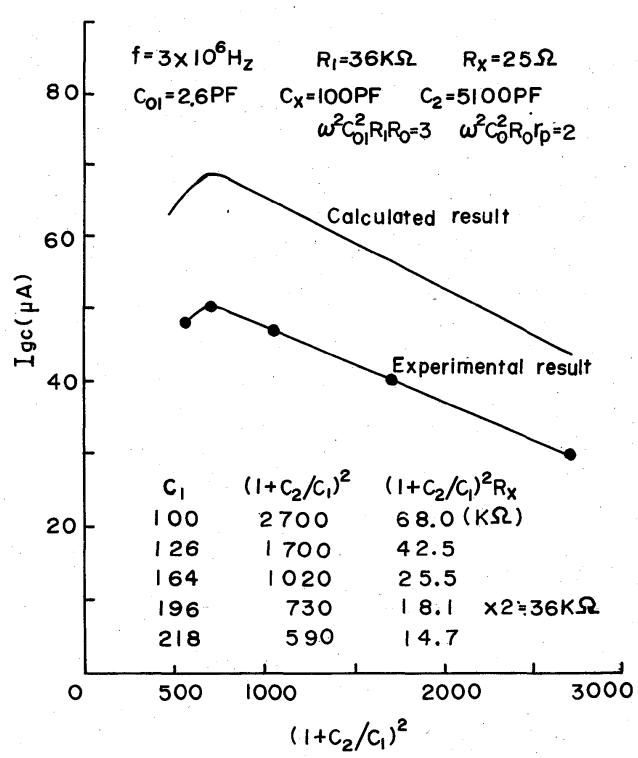

Fig. 4 Calculated and experimental results showing the relation between the output $I_{g c}$ and $\left(1+C_{2} / C_{1}\right)^{2}$ for $C_{x}$

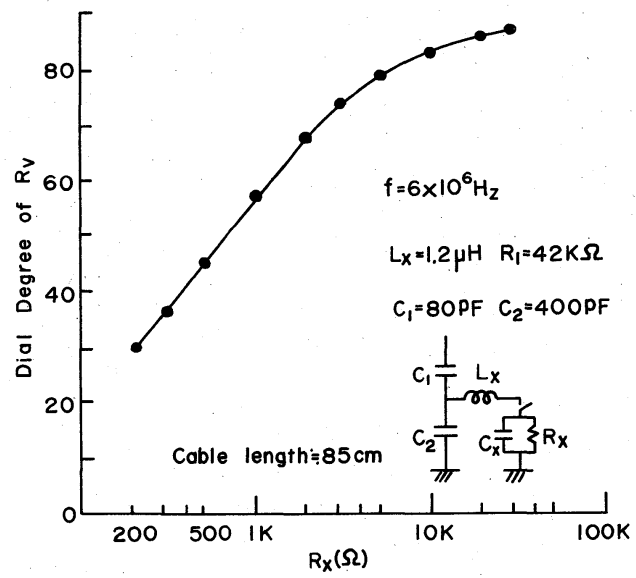

Fig. 5 Relation between $R_{x}$ and the dial degree of vario$\mathrm{hm} R_{v}$ which reduce the output $I_{g R}$ to zero

る容量值，抵抗值の関係を調べたものである．図に示し た電極は，ステンレス製の針(中央が電圧側，外側 2 本が アース側)をアクリル材に固定したもので，BNCコネク タを介して同軸ケーブルで測定器に接続される.つぎに, 本測定器を植物生体情報の検出に用いた例を示す。イネ の茎の静電容量を測定することにより，イネの水分状態 の連続測定を試みた. Fig. 11 に示すように穂首節から約 $10 \mathrm{~cm}$ 下の位置に導電性テープを巻いて電極とし, 再給 水に伴う電極間の茎内静電容量の変化を 30 秒ごとに測 定した。供試品種はインド型陸稲の Salumpikit を用い, 


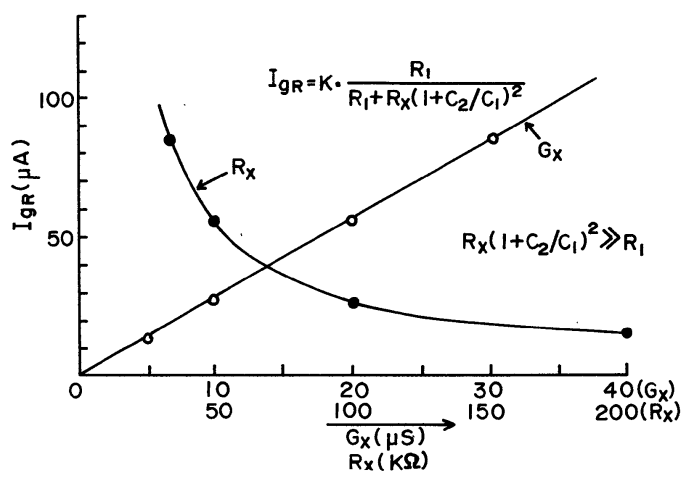

Fig. 6 Experimental results showing the relation between the output $I_{g R}$ and $G_{x}, R_{x}$

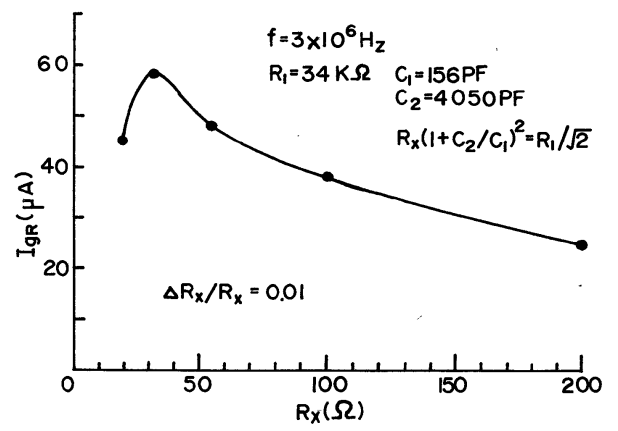

Fig. 7 Relation between the output $I_{g R}$ and $R_{x}(\Omega)$ for the settled small change of $R_{x}\left(\Delta R_{x} / R_{x}=0.01\right)$

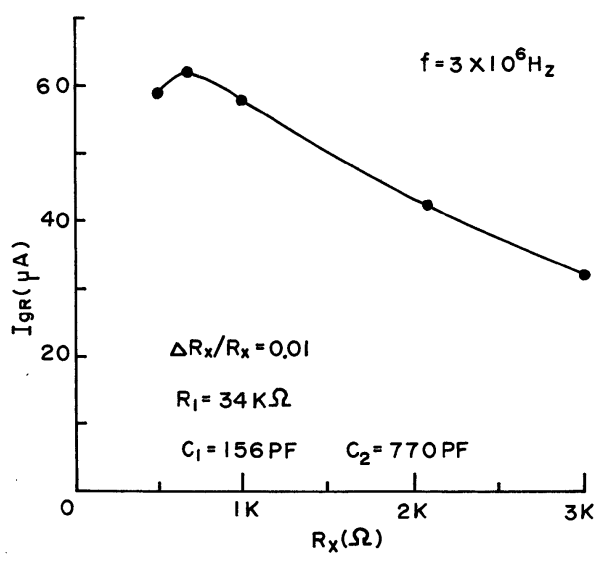

Fig. 8 Relation between the output $I_{g R}$ and $R_{x}(\mathrm{k} \Omega)$ for the settled small change of $R_{x}\left(\Delta R_{x} / R_{x}=0.01\right)$

測定前に潅水を停止して水ストレス処理をしてある.

Fig. 12 に示す曲線 A は, 10 月 28 日(1992)における茥 内静電容量の測定結果であり, 再給水前の葉身は軽い萎 调を示していた.ここに, 出力 $1 \mu \mathrm{A}$ は $0.0088 \mathrm{pF}$ の容量

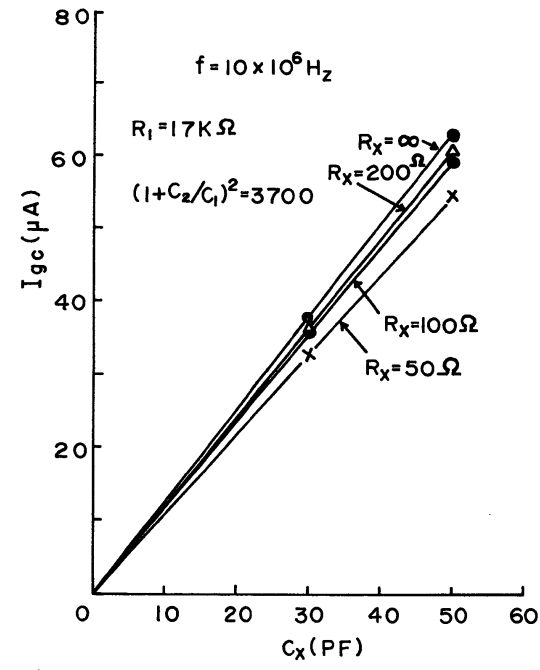

Fig. 9 Relation between the output $I_{g c}$ and $C_{x}$ by deflection method with $R_{x}$ being taken as parameter at $10 \mathrm{MHz}$

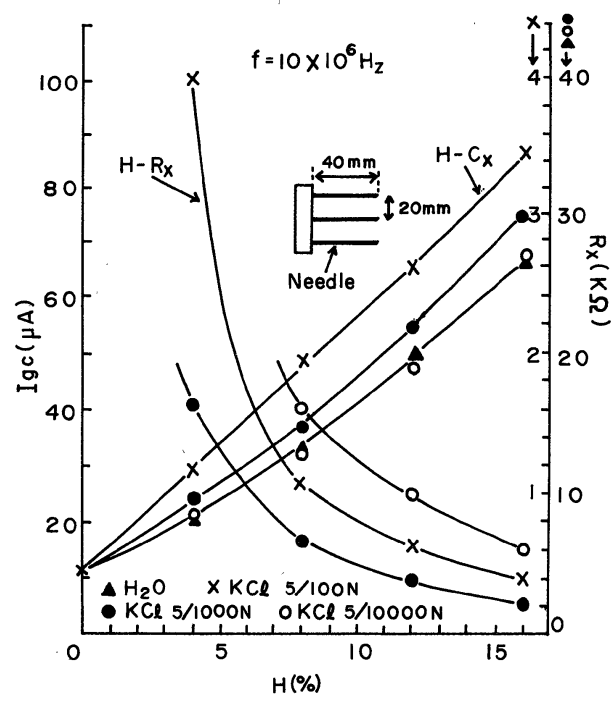

Fig. 10 Relation between moisture $H(\%)$ and $R_{x}, I_{g c}$ of sands by deflection method at $10 \mathrm{MHz}$

值を表わし試料の等価並列抵抗は約 $7 \mathrm{~K} \Omega$ であった. 11 月 6 日 (1992)における静電容量の測定結果を同図の曲線 B, C に示す. B は完全に萎调し葉身が強く巻いた水スト レスの強い状態にあり, Cは軽い萎调を示し, 葉身は軽く 巻いた状態であった。これらの結果から, 水ストレスが 弱い条件下では静電容量值の回復が早く, 水ストレスが 強度になるとその回復に長時間を要す傾向があり, 一番 水ストレスの強い $\mathrm{B}$ の特性は再給水 40 分後もまだ回復 が継続していることを示している.これらの特性は Fig. 
13 に示すように, 著者の 1 人がプレッシャーチェンバー 法で測定した再給水後のイネの葉身水ポテンシャルの回 復の特性とほぼ同じ傾向を示している。 なお Fig. 12 に 示す特性は, 測定時の環境条件(測定時刻，天候)が異な るので, 静電容量の值を直接比較することはできない,

つぎに植物の磁界に対する反応を調べた結果を示す。

Fig. 14 に示すごとく葉の表裏に, 約 $6 \times 6(\mathrm{~mm})$ の導電性 テープを貼って電極とし, 中心半径 $15(\mathrm{~mm})$ の鉄芯入り のコイルに電流を流して磁界を加えた，通電時の磁界の 強さは約 $1000(\mathrm{G})$ であった. Fig. 15 は, カポックを対象 としたときの磁界が葉の抵抗，静電容量に与える影響を 調べたものである．磁界を与えると抵抗，容量值とも短 時間で変化し，磁界を取り去ると短時間でもとの值に回 復している.Fig. 16 はゼラニウムを対象とした結果であ り, 磁界を与えると抵抗, 容量とも徐々にその值を変化 させ，磁界を取り去ってももとの值に回復しない.もち

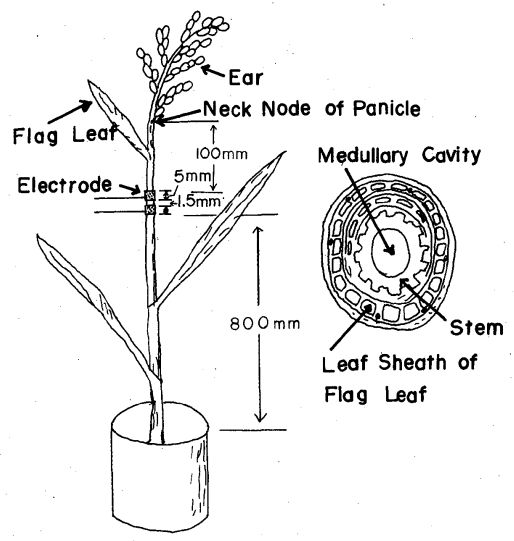

Fig. 11 Schematic diagram of measuring capacitance in rice and cross section of the measured part

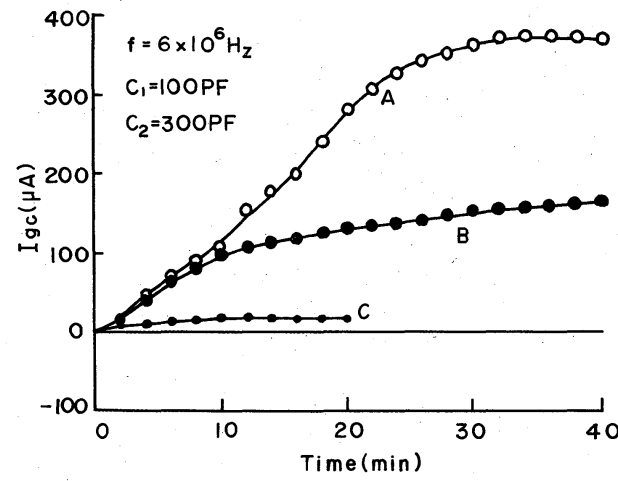

Fig. 12 Changes in the output $I_{g c}$ in rice after the reirrigation in drought pots. A shows the measurement on October 28, and B and C show the measurements on November 6

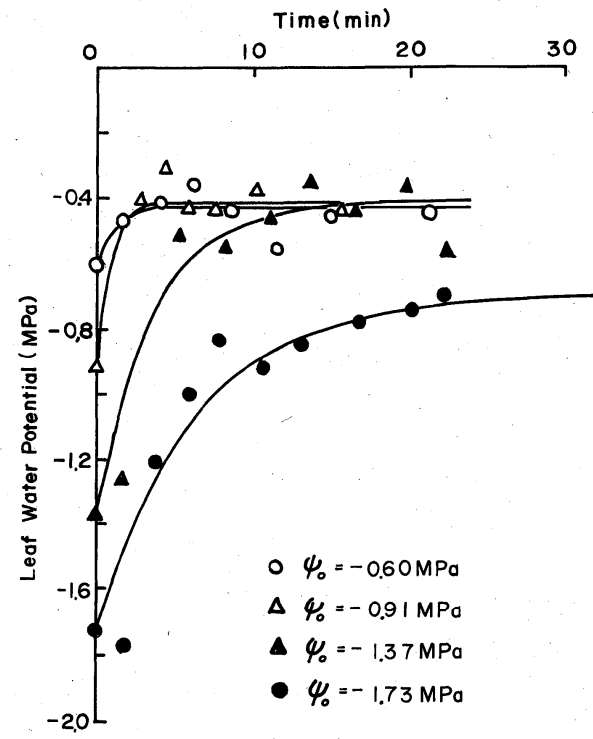

Fg. 13 Changes in leaf water potential in rice after the reirrigation under 4 levels of drought treatments. $\psi_{0}$ shows leaf water potential before the reirrigation

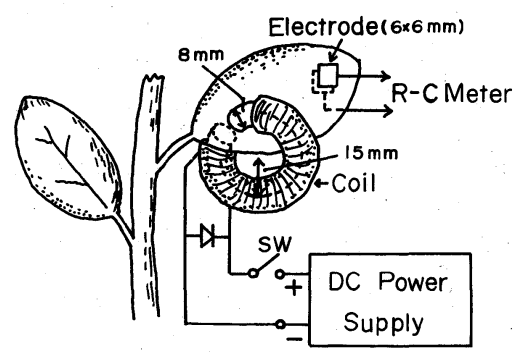

Fig. 14 Schematic diagram of measuring capacitance and resistance in kapok

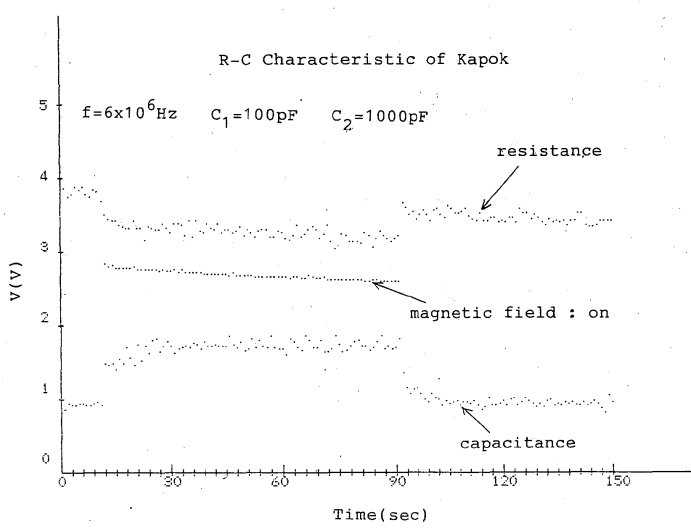

Fig. 15 Effect of magnetic field on capacitance and resistance of the leaf of kapok 


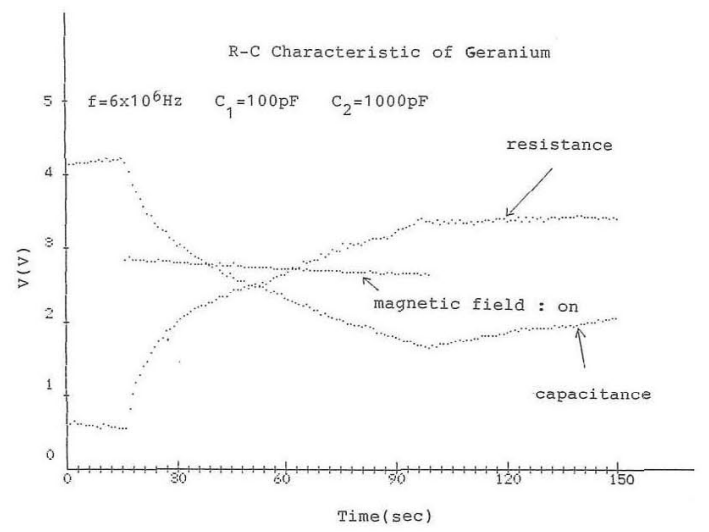

Fig. 16 Effect of magnetic field on capacitance and resistance of the leaf of geranium

ろん，葉を取り去って磁界をかけても(実際にはほぼ同 形，同厚のアクリル板を用いた), 容量, 抵抗の出力に変 化の生じないことを確かめているので,この結果は, 植 物がその種類により磁界に対して異なった反応をするこ とを示している。

\section{5. ま と め}

以上述べたように，2 個の同調回路から構成される低 インピーダンスメータは, 試料の抵抗および容量を零位 法，偏位法のいずれの方法でも測定でき，同時に抵抗の 微少変化の測定も可能である。回路構成が簡単であるの で小型で安価に製作でき工業，医学，特に農業分野での 応用が期待される。応用例でも述べたように, 植物生体 の葉身水ポテンシャルの測定にはサイクロメータ法とプ レッシャーチェンバ法があり, サイクロメータ法には連 続測定した例(7) 9) もあるがこれらは破壞測定が主である ため一般に連続測定は困難である。茎や葉身に破生通気 腔と呼ばれる空隙をもっているイネについても, 本実験 により水分状態の連続測定の可能性が示唆された。

最後に, 本研究は (財)「新技術開発財団」の助成を受 けたことを付記します。

\section{参 考 文 献}

1) B. Ichijo, Y. Masuda, N. Ohkohchi and M. Fujino: Highly Stabilized Circuit for Measuring Very Low Impedance $\left(R_{x}, C_{x}\right)$ and Their Small Changes $\left(\Delta R_{x}\right.$, $\left.\Delta C_{x}\right)$ at High Frequencies with Some Applications, IEEE Transactions on Instrumentation and Measurement, IM-35-3, 293/299 (1986)

2) B. Ichijo and T. Arai : A New Method of Measuring Dielectric Property of Very High Loss Materials at High Frequencies, IEEE Trans., IM-19-1, 73/77 (1970)

3) Y. Masuda, N. Nishikawa and B. Ichijo: New Methods of Measuring Capacitance and Resistance of
Very High Loss Materials at High Frequencies, IEEE Trans., IM-29-1, 28/36 (1980)

4) B. Ichijo, Y. Masuda and K. Abe: A Differential Capacitor Circuit for Very High and Low Dielectric Q -Factor Measurement at High Frequencies, IEEE Trans., IM-22-4, 315/319 (1973)

5) B. Ichijo, Y. Masuda, N. Tarao and M. Sada: Widely Extended New Method for Measuring the Impedance $\left(C_{x}, R_{x}\right)$ at High Frequencies with Applications, IEEE Trans., IM-38-1, 64/73 (1989)

6) B. Ichijo: On the New Method of Measuring Dielectric Constant and Loss Angles of Semiconductors, J. Appl. Phys., 24-3, 307/311 (1953)

7) J.S. Boyer, : Relationship of Water Potential to Growth of Leaves, Plant Physiol., 43, 1056/1062 (1968)

8) P. W. Brown, and C. B. Tanner : Alfalfa Water Potential Measurement, A Comparison of the Pressure Chamber and Leaf Dew-Point Hygrometer, Crop Sci., 240/244 (1981)

9) K.A.Shackel, : Theoretical and Experimental Errors for in situ Measurements of Plant Water Potential, Plant Physiol., 75, 766/772 (1984)

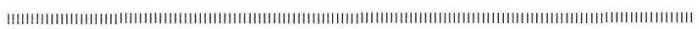

\section{[著 者 紹 介]}

\section{増 田 好 治 (正会員)}

1964 年, 静岡大学工学部電気工学科卒 業. 同年日本コロムビア(株) 入社. 66 年静 岡大学教育学部助手. 82 年教授, 現在に至 る. 高周波低インピーダンスの測定法の開 発およびその応用に関する研究に従事(工 学博士)。電気学会, IEEE, 日本 ME 学会 などの会員。

\section{一 條 文二郎}

1929 年, 山梨高等工業專門学校電気科卒 業。旅順工科大学, 理化学研究所, 東京大 学総合試験所，海軍技術研究所，名古屋大 学を経て, 1952 年静岡大学工学部に勤務。 1972 年退官.この問主として高周波精密計 測に関する研究に従事。 69 年 IEEE ウイリ アム・ジー・テューラー記念賞 (I. G. A グ ループ), おなじく 71 年, 論文賞 (P.M グ ループ)を受賞. 静岡大学名誉教授。現在, 浜松衛生短期大学付置生物環境医療工学研 究所長. IEEE (L. M)の会員 (工学博士).

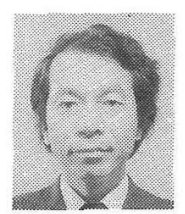

\section{藤 井道 彦}

1988 年, 京都大学大学院農学研究科修士 課程修了. 1990 年, 同大学大学院農学研究 科博士課程中退, 同年静岡大学教育学部技 術科助手, 現在に至る。イネ, 水ストレス, 非破壞計測の研究に従事(農学修士)。

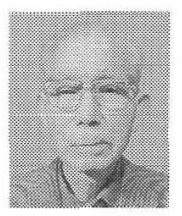

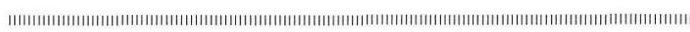

